\title{
Жилищный вопрос в советской и постсоветской России: трансформация отношений собственности и повседневная политика ${ }^{1}$
}

\author{
Н.П. РЫЖОВА*, Т.Н. ЖУРАВСКАЯ**
}

\begin{abstract}
*Наталья Петровна Рыжова - доктор экономических наук, профессор, заведующая Приморской лабораторией экономического развития и сотрудничества, Институт экономических исследований ДВО РАН. Адрес: 680042, Хабаровск, Тихоокеанская ул., д. 153. E-mail: n.p.ryzhova@gmail.com

**Татьяна Николаевна Журавская - кандидат социологических наук, доцент Школы экономики и менеджмента, Дальневосточный федеральный университет; научный сотрудник Приморской лаборатории экономического развития и сотрудничества, Институт экономических исследований ДВО РАН. Адрес: 680042, Хабаровск, Тихоокеанская ул., д. 153. E-mail: wellshy@mail.ru
\end{abstract}

Цитирование: Рыжова Н.П., Журавская Т.Н. (2019) Жилищный вопрос в советской и постсоветской России: трансформация отношений собственности и повседневная политика // Мир России. Т. 28. № 3. С. 48-66. DOI: 10.17323/1811-038X-2019-28-3-48-66

В статье сделана попытка применения концепщий повседневной политики и рутинного сопротивления для объяснения процессов трансформациии политической организации и отношений собственности на примере жилищных практик в советской и постсоветской России. Анализируется, как проводились реформы отношений собственности в советское время и как они сказывались на повседневной жизни людей. Показано, что советская политическая организация формировала идеологию, пытаясь изменить раџиональность и практики повседневной жизни. В соответствии с марксистской идеологией, ментальный контроль привел к контролю над материальностью, в результате чего члены правящей партии доминировали над людьми, не обладающими формальными правами собственности. При этом производство «нового советского гражданина» осуществлялось посредством множества бессвязньх, диффузных и повсеместных действий представителей партии, административных единиц и «обычных» людей. Рутинное сопротивление препятствовало полному исчезновению отношений частной собственности, поскольку, несмотря на почти полное отсутствие в формальном поле ее разрешенной формы в со-

1 Статья подготовлена при финансовой поддержке фонда РФФИ (проект № 16-32-00029-ОГН 18 ) «Институт захватного землепользования на Востоке России: исторический и сравнительный анализ». 
ветское время, частная собственность все же существовала, хотя имела определенную культурную специфику (в частности, практики псевдорыночной продажи, обмена, наследования жилья). Формы рутинного сопротивления советского периода стали одним из факторов, способствовавших политической реорганизаџии начала 1990-х. Последуюшие осложнения в реализачии рыночных преобразований, в свою очередь, во многом определялись сопротивлением материальной инфраструктуры, произведенной в советское время, которая продолжает влиять на формы рутинного сопротивления в настоящее время. В результате жилье как материальный объект стало одной из важньх причин неудачной рыночной трансформации в России. Авторы опираются на представленные в академической литературе описания советских жилищных практик и на данные многолетних включенных наблюдений в Санкт-Петербурге, Благовещченске и в одной из деревень Амурской области.

Ключевые слова: права собственности, политическая организация, советская жилищная политика, рутинное сопротивление, советские и постсоветские повседневные взаимодействия, материальная инфраструктура, повседневная политика

\section{Введение}

Идея о том, что политическая организация и отношения собственности неразрывно связаны, не нова, и то, что трансформация одного приводит к изменению (или требуется для изменения) другого, представляется даже банальным. Теоретическое развитие идеи о связи политической организации и отношений собственности можно проследить, начиная с работ К. Маркса и Ф. Энгельса, которые определяли частную собственность как классово-антагонистическую форму присвоения материального богатства, как совокупность производственных отношений общества и идеологии ${ }^{2}$ [Marx, Engels 1965]. Она не потеряла своей актуальности и для современных экономистов, которые полагают, что для рыночных трансформаций, успешного политического и экономического развития требуются создание и развитие частной собственности [Acemoglu, Johnson, Robinson 2005; Attwood 2012; Alchian, Demsetz 1973; Besley, Ghatak 2009; McFaul 1995; Pipes 1999].

Теоретической идее «повезло»: она была не раз апробирована на практике, в том числе в России. При создании советской политической организации упразднение частной собственности стало важнейшим инструментом коммунистов, и, наоборот, стремление к ней являлось навязчивой идеей рыночных реформаторов в России 1990-х гг. Однако вряд ли процесс трансформации собственности приводил к тем последствиям, которые предполагались или, по крайней мере, заявлялись реформаторами. Существует богатое разнообразие объяснений причин провалов, в котором особое и, возможно, преобладающее место занимают работы, посвя-

2 «Класс, который имеет в своем распоряжении средства материального производства, одновременно контролирует средства умственного производства. < ..> Лица, составляющие правящий класс, обладают, среди прочего, сознанием и, следовательно, могут думать. Поэтому, поскольку они правят как класс и определяют величие и направление эпохи, очевидно, что они делают это во всем диапазоне, следовательно, среди прочего, правят также как мыслители, как производители идей, и регулируют производство и распространение идеи в своем времени» [Marx, Engels 1965, p. 61]. 
щенные институциональным, культурно-специфичным особенностям российской власти [Roland, Aoki, Milgrom, Greif 2004; Walder, Isaacson, Lu 2015; Oleynik 2005]. В этой литературе, связывающей провалы реформ, политические институты и права собственности, остается, на наш взгляд, значительный пробел. Он заключается в том, что для социологов, экономистов и политологов политика - это понятие, так или иначе касающееся государства, его представителей и, наконец, правящих элит, но не жизни «обычных» людей, которые интересны социальным антропологам ${ }^{3}$. Поэтому в настоящей статье представлена попытка объяснения процессов трансформации собственности сквозь призму концепций повседневной политики и рутинного сопротивления [Crawshaw, Jackson 2010; Gupta 2001; Hobson, Seabrooke 2009; O’Brien 1996; O’Neill, Gary 1994].

Пожалуй, наиболее известная работа в этой области была опубликована Дж. Скоттом. Отталкиваясь от идеи М. Фуко [Foucault 1978] о том, что повседневная власть приводит к существованию рутинного сопротивления, Дж. Скотт проанализировал механизмы сопротивления доминированию крестьян Азии [Scott 1985]. Он постоянно задавался вопросом, почему рутинное сопротивление не перерастало в направленное и открытое, не приводило к революции; почему угнетенные продолжали страдать, не стремились к реальным изменениям в политической сфере и не реализовывали в полной мере свои права? Отвечая на эти вопросы, он пришел к выводу, что стремление к рутинному сопротивлению при определенных условиях может стать фундаментом для будущей коллективной мобилизации и политической реорганизации.

В представленной статье мы ставим задачей определить, как повседневная политика и рутинное сопротивление в отношении реформ отношений собственности влияют на «большую политику» или на политическую организацию. Аргумент статьи состоит в том, что рутинное сопротивление стало одним из факторов, способствовавших политической реорганизации начала 1990-х гг. Последовавшие затем проблемы реализации реформы отношений собственности во многом были связаны с сопротивлением материальной инфраструктуры. Мы сосредоточимся на советских и постсоветских жилищных отношениях собственности ${ }^{4}$, которые всегда имели большое значение для советских и постсоветских людей с точки зрения ограниченности и ценности.

Эмпирически мы опираемся на представленные в академической литературе описания советских жилищных практик, на данные включенного наблюдения в Санкт-Петербурге и Благовещенске, а также в одной из деревень в Амурской области. Так, один из авторов имеет опыт проживания в общежитии в СанктПетербурге в течение пяти лет (1992-1997 гг.); в Благовещенске оба автора прожили много лет в разных условиях, в том числе в семейных общежитиях 5 , домах без коммунальных удобств и многоквартирных домах (как в позднесоветский, так

\footnotetext{
3 Например, исследование М. Глакмана, проведенное в Зулуленде (Южная Африка) [Gluckman 1965], которое является одним из примеров антропологического применения подхода К. Маркса к отношениям собственности. М. Глакман показал, что права собственности в Зулуленде частично совпадали, а доступ к земле зависел от социального статуса в политической иерархии. Он интерпретировал собственность в Зулуленде как конфликтующие отношения между «сословием (estates) администрации» (людьми, которые управляли, но не владели землей) и «сословием производства» (люди, которые использовали землю).

4 Этой идее мы обязаны [Dunn, Verdery 2011].

5 Один из авторов статьи прожил в общежитии с 1997 по 2008 г.
} 
в постсоветский периоды). Выбор Санкт-Петербурга обусловлен, в том числе, его достаточной представленностью в литературе, а Благовещенск выделен по причине длительности и вариативности наблюдения. Паттерны повседневной жизни, безусловно, различны, поскольку Санкт-Петербург - вторая столица, а Благовещенск - отдаленный областной центр, расположенный на границе с Китаем, однако мы не сравниваем практики в этих городах: оба города имеют типичные для российской материальной повседневности варианты жилищной инфраструктуры. В статье использовано также описание случая, который наблюдал один из авторов в маленьком поселке Благовещенского района Амурской области, где проживали родители ее матери.

\section{Политическая реорганизация жилищной сферы как форма повседневной власти}

После Октябрьской революции в молодом социалистическом государстве сразу же была отменена частная собственность; государству перешли не только заводы, дороги и шахты, но и жилые дома и квартиры. Идеологически это оправдывалось исключением эксплуатации со стороны владельцев средств производства ${ }^{6}$ жилье было изъято из собственности человека/домохозяйства, поскольку сдача в аренду или продажа жилья могли приносить деньги. Однако в соответствии с видением марксистской идеологии ментальный (духовный) контроль привел к контролю над материальным, в результате чего правящая партия стала доминировать над людьми, не обладающими формальными правами собственности.

По идеологическим причинам, а также из-за невозможности предоставления необходимой инфраструктуры в постреволюционной дезорганизованной экономике [Humphrey 2005] владельцам элитных квартир в Санкт-Петербурге пришлось оставить часть принадлежащих им помещений, чтобы государство могло обеспечить бедных граждан необходимым жильем; позже власти осознали его нехватку и начали процедуру уплотнения ${ }^{7}$, которая означала сокращение жилой площади на одного человека [Герасимова 2000, с. 7]. Это совместное использование жилого фонда было распространено по большей части в крупных городах, особенно в Санкт-Петербурге. Проживание в коммунальной квартире оказалось очень тяжелым испытанием: «полное ссор и конфликтов, грязных и, как правило, неприятных, сломанных приборов» [Humphrey 2005, p. 12]. Для создания и реализации советской жилищной политики было необходимо разработать плановые стандар-

\footnotetext{
6 Например, статья 9 Конституции 1936 г. гласила: «Наряду с социалистической системой хозяйства, являющейся господствующей формой хозяйства в СССР, допускается законом мелкое частное хозяйство единоличных крестьян и кустарей, основанное на личном труде и исключающее эксплуатацию чужого труда». На практике собственность крестьян и кустарей была запрещена, а те, кто владел землей, коровой, лошадью и другими средствами производства, были либо уничтожены, либо разорены, либо отправлены в тюрьмы. Это подтверждает нашу точку зрения, что законные права были заменены административными правами или, вернее, режимом.

7 «Уплотнение» - термин, который коммунисты использовали для определения массовой операции расселения в квартирах такого количества семей, который соответствовал бы числу комнат, вне зависимости от происхождения, профессии или личной истории жильцов. Для лидеров, и в первую очередь для Ленина, это было и решение жилищного кризиса, и идеологический прорыв [Messana 2011, p. 8]. «Некоторые комнаты были разделены на две семьи, знаешь, и не на пару дней, а годами. Вы можете представить две целые семьи в одной спальне?» [Messana 2011, p. 12].
} 
ты, которые должны были выражаться не в помещениях (чтобы избежать «несправедливости»), а в квадратных метрах на человека (8,25 кв.м в 1919 г.) [Герасимова 2000, с. 8]. Это означало, что в одной комнате могли жить не только семьи из двух или четырех человек, но также люди, которые вообще не были связаны родственными узами. Кроме того, появились новые категории - «излишки» (бывшие богатые люди должны были покинуть свои комнаты или квартиры) и «остаток больше метра» («лишние» метры в квартире) [Герасимова 2000, с. 12]. Это было насилием не только в отношении бывших богатых людей, но и бывших бедных, которые стремились избегать совместного проживания с бывшими владельцами помещений и образованными людьми, потому что для них эти условия были непривычными. Тем не менее власти настаивали на этих дисциплинарных мерах и убеждали людей заселять квартиры высокого качества. Другими словами, жилищная политика предполагала, что коммунистическая идеология проникнет в жизнь всех людей и будет встроена в сознание, несмотря на их нежелание.

Еще один способ изменить образ жизни людей с помощью жилищной политики - учреждение коммун - был применен в 1920-х гг. Власти предполагали, что в коммунах люди разного возраста и пола, не связанные родственными связями, могут жить вместе в одном доме как коммунисты или члены одного трудового коллектива. Для этого власти использовали не только заселение в старые дома, но и инициировали новое планирование и строительство. Эти планы были воплощены в рабочих и студенческих общежитиях при фабриках, строительных площадках и университетах [Humphrey 2005]. Однако очевидная неэффективность коммуны (грязь, ссоры и распущенность) помешала государству развить эту форму: из-за экономического кризиса, нехватки дров и процедуры уплотнения некоторые здания были разрушены и заброшены; дома оставались заселенными лишь в течение короткого периода времени, поскольку деревянные материалы (окна, двери, полы) демонтировались для обогрева жилья. Такая реакция на формы повседневной власти (по сути, форма сопротивления, как будет показано ниже) заставили государство частично скорректировать как идеологические, так и материальные методы жилищной политики.

Новые подходы к управлению жилым фондом, начатые в 1930-е гг., включали отказ от коммун, ослабление стандартов нормирования и даже восстановление частной собственности: к концу 1920-х гг. владельцам квартир было разрешено получать прибыль, сдавая помещения арендаторам по установленному государством стандарту (в рублях за квадратный метр) [Герасимова 2000, с. 13]. Однако в 1930-е гг. государство вновь изменило политику, полностью упразднив частную собственность $^{8}$. Хотя стратегия жесткого контроля осталась скрытой от населения и даже от архитекторов [Humphrey 2005], советская жилищная политика следовала логике господства и насилия. Государство начало регулировать личную жизнь, пытаясь построить новую форму общества ${ }^{9}$ вкупе с тотальным контролем над людьми [Humphrey 2005, p. 44]: в 1932 г. паспортная система в сочетании с системой

\footnotetext{
8 Объединения граждан по строительству индивидуального жилья появились в СССР в 1920-х гг., но они были запрещены в 1937 г. как проявление отношений частной собственности.

9 «Мы должны разрушить стены “частной”, “личной”, “собственной” жизни. Мы должны учить людей быть членами коллектива не только на фабрике, но и дома. <..> Дом не добродетельный буржуазный “семейный очаг”, а дом коллективный, дом советской крепости, дом «“кузница” нового житья» [Герасимова 2000, с. 14].
} 
регистрации (пропиской) ограничила мобильность людей между городами и регионами. Например, человеку разрешали переехать в Санкт-Петербург только в том случае, если он получал специальное приглашение на работу; с другой стороны, житель Санкт-Петербурга мог потерять прописку, если уезжал из города на работу или вступал в брак в другом месте ${ }^{10}$. Управление мобильностью осуществлялось и в черте города: К. Хамфри, например, пишет, что советским людям «выделяли жилье обычно по месту их работы или иначе городским советом. < .. > Люди жили в одинаковых многоэтажных домах по соседству, как и все другие работники их предприятий» [Humphrey 2007, p. 185].

Известно, что большинство этих правил, процедур и норм (в том числе и запрет на частную собственность) существовали в той или иной форме до 1990-х гг. Социалистический закон (в частности, Конституция) признавал три типа собственников: государство (государственная форма собственности преобладала), социалистические кооперативы (включая коллективные хозяйства), а также частные лица или домохозяйства, при этом жилье было включено в государственную собственность. Однако можно назвать два исключения, разрешающие существование юридически незакрепленной недвижимости. Первое исключение относилось к работникам Российской академии наук, генералам и инженерно-техническим работникам, добровольно работающим в Сибири. Как писал Г. Берман, одной из причин этого стало то, что после Второй мировой войны власти вынуждены были приспосабливаться к требованиям граждан [Berman 1948]. В отличие от дач функционеров, эти дома, располагавшиеся в поселениях для простых граждан, могли передаваться по наследству. Конечно, владельцы этих дач имели определенные преимущества, но не обладали привилегиями партийных работников. У обычных людей также было право на собственные дома, и это было второе исключение - постройка загородного дома в частном секторе.

В эпоху Н.С. Хрущева (1950-е гг. и позже) жилищная политика была направлена на обеспечение каждого советского домохозяйства отдельным жильем. Программа массовой застройки Н.С. Хрущева широко известна благодаря строительству многоэтажных блоков, но она также включала стимулирование граждан к постройке собственных домов (обычно в деревне) и к участию в кооперативном строительстве. В то время квартиры и загородные дома (дачи) считались (хотя и не по закону $\left.{ }^{11}\right)$ личной собственностью. В начале 1960-х гг. жилищная программа снова кардинально изменилась, и личная собственность подверглась идеологической атаке, хотя никогда полностью вне закона не находилась [Smith 2010]. Несмотря на то, что привилегированные группы населения жили намного лучше (в роскошных квартирах или огромных коттеджах, даже в бывших аристократических резиденциях), к концу советского периода почти каждый гражданин был более или менее комфортно обеспечен со стороны государства недорогим жильем, и это людьми воспринималось как норма.

Как видно, политические решения в отношении управления жильем в советское время были подобны движениям затухающего маятника. Значительная

\footnotetext{
10 «Мать написала письмо Косыгину с просьбой “вернуть” прописку, которую она потеряла, выехав из Перми. Она получила ее через полтора года и нашла работу за 90 рублей в месяц» [Messana 2011, p. 116].

11 Разница между частной и личной собственностью заключалась в возможности получения прибыли: «личная» означает только для личного использования.
} 
нестабильность жилищной политики после революции помогла выработать новую идеологию, привить господство этой идеологии над материальными ресурсами и людьми. Когда новый тип советского гражданина был более или менее сформирован, раскачивание маятника стало менее амплитудным. Так, изменились методы управления: вместо преимущественно негативных приемов (вторжение в частную жизнь, физическое насилие, принудительное перераспределение людей в пространстве) начали использовать позитивные стимулы (обещания улучшить жилье, разрешение на строительство собственного дома в деревне). Это выглядит как иллюстрация идеи Дж. Скотта о «гегемонной идеологии», когда система привилегий, статусов и собственности основывается на утверждении, что она защищает «интересы не только элит, но и подчиненных групп», а для этого необходимо «сделать неявные обещания льгот для подчиненных групп», «что требует некоторых фактических жертв или ограничений со стороны доминирующих групп» [Scott 1985, p. 337]. Мы же не утверждаем, что «производство» идеологии было своего рода направленным действием правящей элиты в марксистском понимании. Совсем наоборот: производство как идеологии, так и «нового советского гражданина» было достигнуто с помощью множества бессвязных, диффузных и повсеместных действий со стороны коммунистической партии, административных единиц, а также физических лиц, «обычных» людей. Замена права административными процедурами стала частью идеологии ${ }^{12}$ и в то же время помогала ее производить. Из этого следует, что представители государства принимали решения не на основании законодательства, а применяя административные процедуры и собственное видение. В результате жилищная политика оказалась не только менее последовательной, но и более диффузной и широкомасштабной. Однако означает ли это, как утверждает Р. Пайпс [Pipes 1999], что в советское время отсутствие юридически закрепленной индивидуальной собственности означало дефицит свободы? Как мы покажем ниже, это представление неверно. Индивидуальная собственность в Советском Союзе сильно отличалась от таковой в западной либеральной традиции, и свобода в отношении собственности представлялась весьма специфичной. Мы согласны с К. Вердери, которая пишет, что, вопреки некоторым западным предположениям о том, что в социализме отсутствует какая-либо система собственности, социализм «был очень сложным» [Verdery 2003, p. 70].

\section{Использование жилья советскими людьми: формы рутинного сопротивления}

Политическая организация жилья была сложна, и в действительности люди жили не так, как им предписывалось. К. Вердери, основываясь на этнографическом исследовании, утверждает, что вокруг вопроса собственности велась «непрерывная борьба» [Verdery 2003, p. 70]. Наши этнографические наблюдения позволяют описать легальные и нелегальные практики, а также экстралегальные (симулирующие

12 «Закон не занимал в социалистических обществах того же места, что и в западных. <...> Собственность в социализме была скорее административным, чем юридическим вопросом» [Verdery 2003, p. 70]. 
легальные) антитехники, используемые советскими гражданами для противодействия системе без применения форм открытой борьбы.

В 1920-х гг. люди сопротивлялись новой жилищной политике весьма изобретательно: например, бывшие владельцы, которые должны были уменьшить площадь в своем жилом помещении, находили родственников, друзей или людей с похожим происхождением, затем они давали объявления в газетах о том, что желают «сдать комнату одинокому, спокойному, солидному интеллигентному жильцу, не рабочему» (цит. по [Герасимова 2000, с. 15]). «Интеллигентный» был своего рода политически нейтральным кодом, определяющим социальный статус: так, в «Красной газете» писали, что «буржуи жулят на все лады. Дабы обезопасить свои жилища от вторжения “рабочей сволочи”, выдумывают несуществующих жильцов, приписывают себе всех своих родных, знакомых» (цит. по [Герасимова 2000, с. 9]).

Советские граждане противостояли жилищной политике и в конце социалистического периода, когда у них появилась возможность строить псевдочастные дома: они отказывались от загородных домов из-за различных ограничений по размеру ${ }^{13}$ или разрешенных коммунальных услуг. Обычные люди не видели привилегию в том, чтобы сначала строить за свой счет дом и затем жить в нем (в частном секторе $)^{14}$, что было связано с трудностями или даже невозможностью подключения дома к отоплению и водоснабжению. Также это было обусловлено требованием регистрации по адресу дома, что в свою очередь, означало обязанность работать в конкретной организации, обычно колхозе. Однако, несмотря на все эти трудности, некоторые граждане решались на это, используя свои ресурсы, связи и навыки. Дедушка одного из авторов, имевший специальные технические навыки, построил электрическую систему отопления, что позволило ему значительно сократить использование древесины и угля, и семья, практически воруя электричество, сократила не только расходы обычного топлива почти на 90\%, но и повседневные усилия. Это не было уникальным для этой деревни случаем: другие семьи также использовали эту «инновационную технологию». Безусловно, эта практика была своего рода «сельской кражей» (rural theft) в терминах Дж. Скотта: «политическое и классовое значение браконьерства было совершенно очевидным, поскольку крестьяне никогда полностью не признавали права собственности тех, кто владел лесами, ручьями, стоками (wastes) и общими ресурсами, которые ранее были совместной собственностью сообщества» [Scott 1985, p. 265].

Некоторые практики существовали в течение длительного времени: например, квартирный обмен, сложившийся в 1920-х гг., продолжился и в 1940-х ${ }^{15}$, и 1970-х гг. ${ }^{16}$, сохранившись вплоть до начала 1990-х гг. Обмены продолжали существовать даже тогда, когда было юридически признано право собственности

\footnotetext{
13 Гражданский кодекс 1964 г. установил ограничение в 60 кв.м.

14 Это зависело от региона, культурных различий и повседневных практик.

15 «После этой драмы мне пришлось продолжать жить с ним, деля одну кухню и ванную. Переехать было невозможно. Кому в Москве захочется жить в двух смежных комнатах с одной дверью в коридор? Если бы у них были отдельные двери, может быть, но в нашем случае никогда не было желающих, мы искали какое-то время, мы даже заплатили кому-то, чтобы сделать это. Тогда это стало слишком дорого и бессмысленно, поэтому мы сдались» [Messana 2011, p. 70].

16 «Я скиталась из коммуналки в коммуналку долгое время. Каждый раз разные проблемы. В 70-е годы я жила в одной комнате в Бибирево в трехкомнатной квартире» [Messana 2011, p. 73].
} 
на жилье. Обмены подразумевали также практику покупки и продажи между частными лицами, как это показывает история семьи одного из авторов. Бабушка по линии отца получила большую квартиру (четыре комнаты) в центре Благовещенска, в которой вместе с ней проживали сын (21 год) и дочь (23 года), у которых уже были свои семьи, и все они были зарегистрированы в этой квартире. После смерти бабушки ее дети обменяли большую квартиру на две меньшей площади. Семья сына (отца одного из авторов) получила двухкомнатную квартиру в деревянном доме с ограниченными коммунальными услугами, другая семья переехала в однокомнатную квартиру со всеми коммунальными удобствами. Год спустя семья автора снова переехала, но уже в хорошую квартиру с двумя комнатами в новом многоэтажном доме в центре города, где у детей была возможность учиться в одной из лучших школ города вместе с детьми партийных работников (при этом родители автора не принадлежали к их числу).

Эта история показывает, что советские граждане имели почти все права собственности в понимании либеральной традиции, в том числе право дарить, наследовать, покупать и продавать собственность, сдавать ее в аренду и т.д. Но эти права не были гарантированными, все операции с недвижимостью зависели от отношений с государством или, точнее, с представителями государства (городскими чиновниками, которые работали в паспортном столе и выдавали вид на жительство в ЖЭК [Humphrey 2007, p. 204]). Обмененные квартиры не принадлежали людям юридически, они не могли быть унаследованы, однако в них мог продолжать жить зарегистрированный там родственник умершего квартиросъемщика ${ }^{17}$. В определенной степени эти экстралегальные практики также помогали избежать пространственного контроля (как уже упоминалось, семья одного из авторов переехала в центр города). Квартиры в СССР можно было даже подарить, для чего снова нужна была только прописка.

Как был устроен обмен? Существовало два способа. В первом случае квартиры фактически обменивали, во втором - квартиру меняли на деньги и прописку («продавали»). В случае реального обмена складывались сложные реципрокные взаимоотношения, поскольку обе стороны обычно не были полностью удовлетворены обменом. Иногда неудовлетворенность могла привести к расторжению сделки, поэтому участники обмена долгое время жили в атмосфере взаимных подозрений. Второй способ фактически означал продажу (как на рынке), а сам формат взаимных обязательств носил краткосрочный характер, и участники сделки старались избегать дальнейших отношений. Особая сложность при «продаже» квартиры состояла в том, чтобы «продавец» получил прописку в другом месте: это могло быть и неравнозначное жилье, например, деревянный дом в деревне. Излишне говорить, что изменение прописки у того, кто «продал» свою квартиру, не должно было привлекать пристального внимания чиновников. В этом случае услуги представителя государства стоили дороже и, в принципе, не могли быть получены без посредника, который в свою очередь стремился к выстраиванию долгосрочных взаимоотношений с чиновниками.

Знала ли городская власть или коммунистическая партия о незаконных сделках? Без сомнения, поскольку все газеты, где публиковались объявления об обме-

17 «Две другие комнаты в квартире были пусты - одна из них пустовала, потому что женщина, которая там была зарегистрирована, умерла до того, как ее дочь смогла прописаться» [Messana 2011, p. 67]. 
нах, находились под полным контролем. В отличие от собственности на землю, где, как пишет К. Вердери, «отсутствовали рутинные правила» [Verdery 1999, р. 55], система собственности на жилье была больше похожа на западную. Конечно, две системы не были эквивалентны, по крайней мере из-за отсутствия или несогласованности правовых норм, но, тем не менее, были очень хорошо развиты рутинизированные правила и практики.

Сложившиеся повседневные практики, конечно, не могли быстро измениться в результате экономических реформ. Люди получили право приватизировать свою собственность в 1988 году. Однако многие из тех, кто хотел их приватизировать и достаточно долго жил в квартирах, считая их «своими», не всегда соответствовали формальным требованиям. Решение при этом всегда было: заплатить, чтобы иметь «правоустанавливающие» бумаги ${ }^{18}$. Кроме того, развивались старые коррупционные практики ввиду несогласованности законодательства (старые правила сосуществовали с новыми), дезорганизованного контроля (советский общественный контроль исчез, в то время как новый гражданский контроль не появился) и из-за новых экономических стимулов. Это привело к появлению огромного числа уголовных дел, лишению прав бывших жителей государственных квартир и появлению многочисленных бездомных. Неудивительно что, в такой ситуации некоторые люди отказались приватизировать собственность, считая государство неспособным защитить их от обмана.

Хотя граждане и пострадали от жилищной политики, вопроса об открытой борьбе никогда не возникало. Согласно анализу сопротивления крестьян Дж. Скотта, можно также увидеть две причины, объясняющие, почему эскалация конфликта так и не случилась. Во-первых, бесспорно, многие люди после революции стали жить лучше: несмотря на длинные очереди ожидания жилья, советские граждане получали его бесплатно. Во-вторых, видимые различия между доминирующими и подчиненными группами оказались незначительными, и сложно было определить, кто должен стать целью в социальном конфликте. Различия были более заметны на высших уровнях и в крупных городах, где они оправдывались идеологией. Но в целом советская социальная структура была неясной, а потому оказалось достаточно сложно найти «цель» для открытого сопротивления, которое было «неорганизованным, бессистемным и индивидуальным», через «символическую, эпизодическую или даже эпифеноменальную (epiphenomenal) деятельность» как способ реагирования на диффузную, неинституционализированную форму господства [Scott 1985, p. 292].

Советские люди хотели «не свергнуть и не трансформировать систему господства, а, скорее, выжить в ней сегодня, на этой неделе, в это время года» [Scott 1985, p. 301]. Возможно, это сопротивление как способ повседневного выживания через рутинизацию рыночного обмена стало одним из факторов, способствовавших переходу к рынку. Разрыв между идеологией прав собственности и повседневными знаниями о них помогли людям принять, а в некоторых случаях даже

18 «Когда у меня будет немного времени, я собираюсь приватизировать свою квартиру, но это практически невозможно. Я приватизировал свою комнату, и через друга адвоката я могу автоматически добавить следующую комнату, которая признана непригодной для проживания из-за шума. Но все очень сложно, поскольку я бы не имел права на свои 25 метров. Я вынужден был сделать себе поддельную справку о том, что я уважаемый художник. Благодаря этой бумаге у меня есть право на дополнительные 10 кв. м» [Messana 2011, p. 114]. 
с энтузиазмом поддержать новую экономическую реальность, сформированную элитами. Тем не менее люди довольно скептически отнеслись к революционным изменениям в отношениях с недвижимостью, не поддержали планы новой платежной системы и налогообложения, новые правила распределения жилья. Более того, люди не спешили приватизировать собственность. Другими словами, каждодневное сопротивление не имеет ничего общего с открытым сопротивлением или революцией.

Таким образом, пример советских жилищных практик подвергает сомнению положение о том, что в социалистических странах не было пространства для собственности. Мы утверждаем, что, напротив, существовала некая частная собственность с определенной культурной спецификой. Социалистическое государство стремилось изменить природу людей путем реализации новой жилищной политики в 1920-1980-х гг. Позже, в 1990-х гг. ${ }^{19}$, широко обсуждалось, что права собственности на жилье («западного» типа) могут снова преобразовать политическую организацию постсоветского общества ${ }^{20}$. Что касается антропологической логики, трансформация капиталистической политической системы на социалистическую (или наоборот) не могли изменить повседневные политические отношения. Анализируя ситуацию с жильем в СССР, мы можем не только проверить это предположение, но и увидеть, что люди сохранили от «старой» политической организации. Возвращаясь к главному вопросу, мы вновь утверждаем, что политическая организация не означает исключительно господство правящих элит. Скорее, политическая организация является следствием повседневных политических действий людей. В следующем разделе мы обсудим то, как жилье само по себе (в терминах Бруно Латура «нечеловеческое существо» (non-human beings) [Latour 2005]) может влиять на имущественные отношения и в более широком смысле - на политическую организацию.

\section{Сопротивление материальной инфраструктуры}

В предыдущем разделе мы упомянули, что советские права собственности были в числе факторов, которые способствовали переходу к рынку. В этом разделе мы обсудим обратную идею: материальные особенности советского жилья стали одной из причин, влияющих на провал рыночных реформ в России. Наш аргумент, основанный на анализе советской инфраструктуры К. Хамфри [Humphrey 2005], заключается в следующем: намерения планировщиков остаются активными в самой материальной структуре зданий даже после того, как поли-

\footnotetext{
19 В 1990-х гг. предполагалось, что частная собственность на жилье «уменьшит зависимость людей от государства» и позволит расширить рыночную экономику [Attwood 2012].

20 Значительные сомнения относительно этого предположения могут появиться после прочтения статьи А. Макфарлена [Macfarlane 1998], проанализировавшего специфику развития индивидуальной собственности в Англии. По его словам, английская традиция допускала раздел имущества, при этом сама вещь оставалась неделимой. Это было первой особенностью, позволившей властям разработать эффективные права собственности; другая касалась политической организации, а именно централизованного феодализма, который также помог сохранить индивидуальные права и неделимые вещи. Этот процесс длился веками, и в других странах не повторился ни разу. Таким образом, ожидания, что капиталистические права собственности могут быть быстро встроены в советское общество, кажутся слишком оптимистичными.
} 
тико-экономический контекст изменился, другими словами, дома являются агентами планировщиков. Жилье в СССР планировали госагенты с целью привить общинный/коммунистический образ жизни ${ }^{21}$, теперь же это жилье мешает людям развивать новые рыночные отношения. Приведенные ниже цитаты из интервью с жителями санкт-петербургской коммуналки демонстрируют повседневные политические отношения в этой сфере:

«Рассказывают о коммуналках, в которых постоянно открывались и закрывались двери или в которых двери были приоткрыты для шпионажа, в которых женщины собирались на кухне, чтобы посплетничать и обсудить частную жизнь других. $<\ldots>$ У нас все было не так, двери были закрыты; всегда было тихо, < ..> никто ни с кем не разговаривал» [Messana 2011, p. 120].

«И потом, жизнь на кухне, которая так важна в этой стране, невозможна в коммуналке. Я не мог пригласить друзей посидеть, а я не люблю принимать гостей в своей комнате. <..> На кухне кто-то мог долго сидеть за столом, болтать, пить и петь» [Messana 2011, p. 74].

«Моим соседям дали отдельную квартиру. < ... Я плакал, как будто кто-то умер. Они оставили мне ключи от своей комнаты, это было незаконно. Было несколько попыток поселить там людей, но не получилось» [Messana 2011, p. 113].

Эти выдержки демонстрируют, что люди по-разному воспринимали жизнь в коммуналках и что она не всегда была ужасной. В отличие от последнего отрывка, первый показывает отсутствие коллективности; в то время как второй выявляет, насколько было сложно человеку защитить свою личную жизнь. Анализ опыта проживания в студенческом общежитии одного из авторов позволяет сделать вывод о том, что восприятие коммунального жилья изменяется в зависимости от обстоятельств ${ }^{22}$. Обе иллюстрации, приведенные в сноске 22, раскрывают важность артефактов (дворов, ванных комнат или коридоров), поскольку повседневная практика реализуется именно на этом фоне. Кухонные разговоры как форма сопротивления во время оттепели были возможны только, когда люди могли сидеть за столом, а запирание дверей сглаживало экстралегальное сопротивление во время застоя. Иными словами, жизнь в коммунальной форме повлияла на повседневную политику через артефакты ${ }^{23}$.

21 Ученые на это имеют разные точки зрения: «Дом - это воплощение автономии и один из гарантированных шансов вернуться в личную жизнь» [Kornai 1992, p. 456]; «Дом (особенно квартира) является частным пространством и полной противоположностью враждебному миру за его пределами» [Fehérváry 2013, p. 18]; «Общежития, узнаваемые от Прибалтики до Владивостока, предназначались для воплощения идей равенства, бережливости, открытости по отношению к другим и общей ответственности» [Humphrey 2005, pp. 46-47].

22 «Будучи студентом, я жила в общежитии в Санкт-Петербурге. Я была шокирована дважды: когда я впервые приехала в этот дом равенства и бережливости после проживания в нашей “собственной” квартире и позже, когда я вернулась в спокойную квартиру моих родителей. Мы делились вещами, вместе готовили и ели, имели свои “клубы” и “группы”. Но не все жили так же. Было две или три семьи, которые жили в отдельных комнатах, имели свои холодильники, никогда не делили кухонную утварь или еду с кем-то, не принимали участия в общественной жизни, никого не приглашали в гости, но мы не осуждали их. Когда я только приехала, я пыталась вернуть прежние условия жизни, но потом я стала получать удовольствие от атмосферы “сумасшедшего” дома».

23 Другими словами, в создании смысла участвуют как материальные, так и нематериальные акторы [Latour 2005]. 
Безусловно, плотность взаимодействий в коммунальной квартире была гораздо выше, чем в отдельных квартирах в многоэтажных домах, тем не менее важность артефактов для жителей становилась очевидной. В подростковом возрасте мы проводили все свободное время во дворах, и представляется странным видеть этот двор как «враждебный мир за пределами квартиры» [Fehérváry 2013]: напротив, там были качели и песочница для детей, футбольное поле для подростков, стол для игры в домино для взрослых и скамейки для бабушек ${ }^{24}$.

C тех пор преобладающая пространственная организация российских жилых районов изменилась незначительно ${ }^{25}$. Различия этой организации в России и, например, в Великобритании, легко определяемы: так, обустройство наиболее массовой викторианской застройки позволяло жителям иметь частное пространство, оставаться относительно независимыми и избегать конфликтов из-за общих территорий (пространство перед дверью принадлежит именно этой двери и этому дому ${ }^{26}$ ). В России же почти невозможно избежать какого-либо контакта с соседями, по крайней мере, посредством артефактов (например, разбитых окон или мусора в лифте). Ссоры чаще всего связаны с общей инфраструктурой, такими как трубы и лестничные площадки (где располагаются дверные проемы квартир ${ }^{27}$. Конечно, конфликты из-за мест общего пользования могут возникнуть и в Великобритании, но почти вся постсоветская материальность делает их неизбежными, поскольку все организовано так, что люди вынуждены постоянно взаимодействовать ${ }^{28}$.

Развитие новых форм управления и поддержания порядка в российских многоквартирных домах (наличие эффективной управляющей компании и консьержа, договоренность с соседями о совместном управлении общей собственностью) сводит конфликты по поводу беспорядка к нулю. Однако перечисленные блага рыночной цивилизации доступны далеко не всем и дифференцированы по уровню дохода и месту проживания (таблища 1).

Многие россияне (люди со средним и низким достатком, жители кризисных моногородов, сельских населенных пунктов с двумя многоэтажками на муниципальное образование, собственники квартир в хрущевках и разрушающихся панельных домах и другие) «схвачены» материальной инфраструктурой и даже при прочих положительных условиях сопротивляются наделению себя общей инфраструктурой. Неслучайно приватизация жилья все еще не завершена: в России

\footnotetext{
24 См., например, картины С. Волкова вот здесь: https://yablor.ru/blogs/hudojnik-volkov-sergey--moskva/340898; в частности, картину «Московский дворик».

25 Погорельский А. (2017) Машинам здесь не место: как бороться с парковкой около дома // РБК. 17 мая 2017 // https://realty.rbc.ru/news/591c4e979a794740789cb799

26 Collins N. (2010) Britain 'Cannot Afford another Housing Boom'// The Telegraph, October 10, 2010 // https://www. telegraph.co.uk/finance/personalfinance/8057907/Britain-can-not-afford-another-housing-boom.html; или фото британских таунхаусов // http://www.geograph.org.uk/photo/240889

27 Лайфхак, или как заставить соседей убрать свой мусор из коридора // https://pikabu.ru/story/layfkhak_ili_kak_ zastavit_sosedey_ubrat_svoy_musor_iz_koridora_4683788

28 Повседневное общение и причины конфликтов по поводу общей инфраструктуры можно проследить, например, посредством объявлений в подъездах: «!!!ВНИМАНИЕ!!! Уважаемые соседи в 2015г. летом на площадке 4 этажа был отставлен Диван не больших размеров коричневого цвета с подушками - вероятнее всего он был присвоен кем то именно с 4 этажа! Очень рад что он вам приглянулся, но настало время его вернуть на место где вы его взяли! ЗА ВОЗНАГРАЖДЕНИЕМ МОЖНО ОБРАТИТЬСЯ ПО НОМЕРУ [объявленИе на площадке, Благовещенск, декабрь 2018 г; орфография и пунктуация сохранены] (другие примеры см.: https:/www.adme.ru/svoboda-narodnoe-tvorchestvo/zhizn-podezda-728510).
} 
в частную собственность перешло около 80\% квартир, а жилье в коммунальных квартирах приватизируется хуже, чем в индивидуальных. И, наконец, понятно, почему в 2016 г. Государственная Дума приняла закон о бессрочной приватизации, тогда как до этого на протяжении 25 лет пыталась установлением сроков продемонстрировать ценность предлагаемого ресурса. Таким образом, особенности материальной инфраструктуры жилого фонда России стимулируют рутинное сопротивление и блокируют изменения политической организации общества.

Таблица 1. Доля домохозяйств, проживающих в многоквартирных домах, оборудованных мусоропроводом, дверью с кодовым замком или домофоном, детской площадкой на придомовой территории, \%

\begin{tabular}{|l|c|c|c|c|c|c|}
\hline \multirow{2}{*}{ Субъект РФ } & \multicolumn{2}{|c|}{ мусоропровод } & \multicolumn{2}{c|}{$\begin{array}{c}\text { дверь с кодовым } \\
\text { замком или домофоном }\end{array}$} & \multicolumn{2}{c|}{$\begin{array}{c}\text { детская площадка } \\
\text { на придомовой } \\
\text { территории }\end{array}$} \\
\cline { 2 - 7 } & $\mathbf{2 0 1 4}$ & $\mathbf{2 0 1 8}$ & $\mathbf{2 0 1 4}$ & $\mathbf{2 0 1 8}$ & $\mathbf{2 0 1 4}$ & $\mathbf{2 0 1 8}$ \\
\hline РФ & $\mathbf{3 2 , 5}$ & $\mathbf{3 5 , 2}$ & $\mathbf{8 0 , 5}$ & $\mathbf{8 5 , 9}$ & $\mathbf{6 6 , 1}$ & $\mathbf{6 9 , 4}$ \\
\hline Санкт-Петербург & 54,1 & 61,9 & 99,0 & 98,9 & 81,4 & 70,9 \\
\hline Амурская область & 7,9 & 0,8 & 63,2 & 62,9 & 55,1 & 76,2 \\
\hline Астраханская область & 24,3 & 16,3 & 70,7 & 77,8 & 64,5 & 76,8 \\
\hline Белгородская область & 35,0 & 44,3 & 97,6 & 85,7 & 76,5 & 86,9 \\
\hline Ленинградская область & 17,7 & 21,4 & 86,1 & 82,3 & 69,4 & 73,8 \\
\hline $\begin{array}{l}\text { Республика Северная } \\
\text { Осетия-Алания }\end{array}$ & 38,7 & 30,0 & 51,0 & 59,6 & 22,0 & 73,3 \\
\hline Самарская область & 52,5 & 43,8 & 94,4 & 88,3 & 71,4 & 73,8 \\
\hline $\begin{array}{l}\text { Ханты-Мансийский } \\
\text { автономный округ }\end{array}$ & 21,6 & 47,7 & 70,1 & 77,5 & 68,8 & 64,9 \\
\hline
\end{tabular}

Источник: Итоги федеральных статистических наблюдений по социально-демографическим проблемам // http://www.gks.ru/free_doc/new_site/inspection/itog_inspect1.htm

\section{Заключение}

Советская идеология и жилищная политика, предназначенные для производства «подходящих» граждан, имели более неоднозначный характер по сравнению с постсоветской эпохой. «Обычные люди» (более или менее «подходящие») жили по-своему. По образу жизни отличить элиты от «обычных людей» было нелегко, поскольку привилегии первых часто были подкреплены идеологией. Сопротивление граждан коллективному образу жизни, которое навязывало советское государство, фактически препятствовало исчезновению отношений частной собственности, в результате чего идеология также трансформировалась. Советская государственность была изменена не только посредством нематериальной ментальности, рациональности или техник, но и благодаря материальной структуре. Архитектура со своими артефактами в качестве актора отношений собственности формировала 
и преображала политическую организацию. Однако будучи произведенными, материальные изменения продолжают оказывать влияние на рутинное сопротивление и в настоящее время: люди не хотят владеть коллективной собственностью, уклоняются от уплаты за нее, с трудом договариваются об управлении общедомовыми территориями, о выборе форм управления и т.п. Ввиду того, что экономически более успешные россияне живут в иных по сравнению с обитателями хрущевок условиях, можно сделать предположение, что материальная инфраструктура сама формирует людей с различными паттернами принятия решений по поводу отношений собственности.

Конечно, с точки зрения экономистов эти рассуждения выглядят довольно странно. Для мейнстрима экономической теории отношения между собственностью и политической организацией представляются достаточно простыми: необходимо добиться эффективного использования дефицитных экономических ресурсов, для чего требуются определенная политическая организация (капитализм) и специальные институты, гарантированные государством и защищающие права собственности. Согласно экономической теории, только при капитализме у владельца есть стимулы контролировать доступ к вещам и принимать лучшие индивидуальные решения о том, как максимально эффективно их использовать [Alchian, Demsetz 1972]. Исходя из этого, экономисты изобрели рецепт исправления слабых постсоциалистических или постколониальных экономик. Наиболее ярким примером этого стал Вашингтонский консенсус (или стандартный пакет реформ), предложенный Международным валютным фондом и Всемирным Банком для развивающихся стран, пострадавших от кризиса. Консенсус включал в себя приватизацию и правовое обеспечение прав собственности вместе с десятью другими конкретными рекомендациями по экономической политике. Однако политические эксперименты показали, что введение прав частной собственности в качестве необходимой дисциплинарной меры для экономического роста не сработало так, как ожидалось, и появление капитализма привело к деколлективизации, перераспределению прав собственности [Verdery 1999, 2003; Hann 2003], лишению прав собственности [Elyachar 2005] и достаточно редко - к желаемым экономическим показателям.

Следуя логике настоящей статьи, для производства новых граждан, соответствующих рыночной идеологии, должны быть изменены не только законодательство, ментальность, рациональность, техники и коррупционные отношения, но и материальная инфраструктура, что представляется совершенной утопией. Поэтому в ближайшие годы Россия вряд ли сможет построить западную рыночную экономику, основанную на правах частной собственности.

\section{Литература}

Герасимова Е.Ю. (2000) Жилье в советском городе: историко-социологическое исследование (Ленинград, 1918-1991) // http://ecsocman.hse.ru/rubezh/msg/16298294.html

Ермишина А., Клименко Л. (2010) В поисках эффективного собственника в многоквартирном доме // Экономическая социология. Т.11. № 4. С.105-136.

Acemoglu D., Johnson S., Robinson J.A. (2005) Institutions as a Fundamental Cause of LongRun Growth // Handbook of Economic Growth (eds. Aghion P., Durlauf S.N.), vol. 1A, New York: Elsevier, pp. 385-472. 
Alchian A.A., Demsetz H. (1972) Production, Information Costs, and Economic Organization // American Economic Review, vol. 62, no 5, pp. 777-795.

Attwood L. (2012) Privatisation of Housing in post-Soviet Russia: A New Understanding of Home? // Europe-Asia Studies, vol. 64, no 5, pp. 903-928.

Berman H.J. (1948) Soviet Property in Law and in Plan (with Special Reference to Municipal Land and Housing) // University of Pennsylvania Law Review, vol. 96, no 3, pp. 324-353.

Besley T., Ghatak M. (2009) Property Rights and Economic Development // Handbook of Development Economics (eds. Rodrik D., Rosenzweig M.), vol. 5, Oxford: Elsevier, pp. 4525-4595.

Crawshaw J., Jackson J. (2010) Small Acts of Resistance: How Courage, Tenacity, and Ingenuity Can Change the World, New York: Union Square.

Dunn E.C., Verdery K. (2011) Dead Ends in the Critique of (post)Socialist Anthropology: Reply to Thelen // Critique of Anthropology, vol. 31, no 3, pp. 251-255.

Elyachar J. (2005) Markets of Dispossession: NGOs, Economic Development, and the State in Cairo, Durham: Duke University Press.

Fehérváry K. (2013) Politics in Color and Concrete: Socialist Materialities and the Middle Class in Hungary, Indiana University Press.

Foucault M. (1978) The History of Sexuality. Vol. 1: An Introduction, New York: Random House.

Gerasimova K. (1999) The Soviet Communal Apartment // Beyond the Limits: The Concept of Space in Russian History and Culture (ed. Smith J.), Helsinki: Studia Historica, pp. 107-130.

Gerasimova K. (2002) Public Privacy in the Soviet Communal Apartment // Socialist Spaces. Sites of Everyday Life in the Eastern Bloc (eds. Crowley D., Reid S.E.), New York: Berg Publishers, pp. 207-230.

Gluckman M. (1965) Politics, Law and Ritual in Tribal Society, Oxford: Basil Blackwell.

Gupta D. (2001) Everyday Resistance or Routine Repression? Exaggeration as Stratagem in Agrarian Conflict // Journal of Peasant Studies, vol. 29, no 1, pp. 89-108.

Hann C.M. (ed.) (1998) Property Relations: Re-newing the Anthropological Tradition, Cambridge, UK: Cambridge Universe Press.

Hann C.M., the Property Relations Group (2003) The Post-socialist Agrarian Question: Property Relations and the Rural Condition, Münster: LIT Verlag.

Hobson J., Seabrooke L. (2009) Everyday Politics of the World Economy, New York: Cambridge University Press.

Humphrey C. (1983) Karl Marx Collective: Politics, Society and Religion on a Siberian Collective Farm, Cambridge: Cambridge University Press.

Humphrey C. (2005) Ideology in Infrastructure: Architecture and Soviet Imagination // The Journal of the Royal Anthropological Institute, vol. 11, no 1, pp. 39-58.

Humphrey C. (2007) New Subject and Situated Interdependance: after Privatization in Ulan-Ude // Urban Life in post-Soviet Asia (eds. Alexander C., Buchli V., Humphrey C.), London, pp. $175-207$.

Humphrey C. (2013) Fear as a Property and an Entitlement // Social Anthropology, vol. 21, no 3, pp. 285-304.

Kideckel D.A. (1976) The Social Organization of Production on a Romanian Cooperative Farm // Dialectical Anthropology, vol. 1, no 3, pp. 267-276.

Kornai J. (1992) The Socialist System: The Political Economy of Communism, Oxford: Oxford University Press.

Latour B. (2005) Reassembling the Social: An Introduction to Actor-Network-Theory, Oxford: Oxford University Press.

Macfarlane A. (1998) The Mystery of Property: Inheritance and Industrialization in England and Japan // Property Relations (ed. Hann C.M.), University of Kent at Canterbury, pp. 104-123.

Marx K., Engels F. (1965/1932) The German Ideology, London: Lawrence \& Wishart.

McFaul M. (1995) State Power, Institutional Change, and the Politics of Privatization in Russia // World Politics, vol. 47, no 2, pp. 210-243.

Messana P. (2011) Soviet Communal Living. An Oral History of the Kommunalka, Palgrave Macmillan.

O’Brien K.J. (1996) Rightful Resistance // World Politics Journal, vol. 49, no 1, pp. 31-55. 
O’Neill T., Gary H. (1994) All Politics Is Local, New York: Times Books.

Oleynik A. (ed.) (2005) The Institutional Economics of Russia's Transformation, Routledge.

Pipes R. (1999) Property and Freedom, London: Harvill.

Roland G., Aoki M., Milgrom P., Greif A. (2004) Transition and Economics: Politics, Markets, and Firms, MIT Press; New Ed edition.

Scott J.C. (1985) Weapons of the Weak: Everyday Forms of Peasant Resistance, New Haven: Yale University Press.

Smith M.B. (2010) Property of Communists: The Urban Housing Program from Stalin to Khrushchev, DeKalb: Northern Illinois University Press.

Verdery K. (1999) Fuzzy Property: Rights, Power and Identity in Transylvania's Decollectivization // Uncertain Transition: Ethnographies of Change in the Post-socialist World (eds. Burawoy M., Verdery K.), Lanham, Md.: Rowman \& Littlefield, pp. 53-82.

Verdery K. (2003) The Vanishing Hectare: Property and Value in Post-socialist Transylvania, Ithaca, NY: Cornell University Press.

Verdery K., Humphrey C. (eds.) (2004) Property in Question: Value Transformation in the Global Economy, Oxford: Berg.

Walder G., Isaacson A., Lu Q. (2015) After State Socialism: The Political Origins of Transitional Recessions // American Sociological Review, vol. 80, no 2, pp. 444-468.

\title{
Housing in Soviet and post-Soviet Russia: The Transformation of Property Relations and Everyday Resistance
}

\author{
N. RYZHOVA*, T. ZHURAVSKAYA**
}

\begin{abstract}
*Natalia Ryzhova - DSc in Economics, Professor, Economic Research Institute of the Far Eastern Branch of the Russian Academy of Sciences, PaRuS. Address: 153, Tikhookeanskaya St., Khabarovsk, 680042, Russian Federation. E-mail: n.p.ryzhova@gmail.com

**Tatiana Zhuravskaya - PhD in Sociology, Associate Professor, School of Economics and Management of the Far Eastern Federal University; Researcher, Economic Research Institute of Far Eastern Branch of the Russian Academy of Sciences, PaRuS. Address: 153, Tikhookeanskaya St., Khabarovsk, 680042, Russian Federation. E-mail: wellshy@mail.ru
\end{abstract}

Citation: Ryzhova N., Zhuravskaya T. (2019) Housing in Soviet and post-Soviet Russia: The Transformation of Property Relations and Everyday Resistance. Mir Rossii, vol. 28, no 3, pp. 48-66 (in Russian). DOI: 10.17323/1811-038X-2019-28-3-48-66

\section{Abstract}

In this article, we apply the concepts of 'everyday politics' and 'routine resistance' to explain the transformation of political organization and property relations in housing practices in Soviet and post-Soviet Russia. Specifically, we discuss how property relations were reformed during the Soviet period and how they affected the daily life of ordinary people. We show that Soviet political organization molded a specific ideology in an attempt to change rationality and everyday life. In accordance with Marxist ideology, the control over people's minds led to control over material things. As a result, the ruling 
party and its members dominated without possessing formal property rights, while the production of the ideology and the molding of a "new Soviet citizen" was conditioned by a number of incoherent, diffuse and omnipresent actions by representatives of the Communist Party, administrative units and ordinary people. Routine resistance prevented the complete disappearance of private property relations. Despite its formal non-existence in the Soviet era, private property did exist, albeit vested in a specific cultural form (e.g. in the practices of pseudo-market selling, exchange and inheritance). Such forms of routine resistance in the Soviet period were one of the factors that contributed to the political reorganization of the early 1990s. The ensuing difficulties in the implementation of private property relations that followed were largely due to the resistance of the 'material infrastructure' from the Soviet era. This material infrastructure continues to influence routine resistance, for example, people do not want to own collective property or they evade payment for it. As a result, housing as a material object has become one of the important causes of the unsuccessful market transformation in Russia. Empirically we draw on the descriptions of Soviet housing practices in the academic literature and the data collected during many years of observations in St. Petersburg and Blagoveshchensk, in a village in the Amur Region.

Key words: property rights, political organization, Soviet housing policy, routine resistance, Soviet and post-Soviet daily interactions, material infrastructure, daily politics

\section{References}

Acemoglu D., Johnson S., Robinson J.A. (2005) Institutions as a Fundamental Cause of LongRun Growth. Handbook of Economic Growth (eds. Aghion P., Durlauf S.N.), vol. 1A, New York: Elsevier, pp. 385-472.

Alchian A.A., Demsetz H. (1972) Production, Information Costs, and Economic Organization. American Economic Review, vol. 62, no 5, pp. 777-795.

Attwood L. (2012) Privatisation of Housing in post-Soviet Russia: A New Understanding of Home? Europe-Asia Studies, vol. 64, no 5, pp. 903-928.

Berman H.J. (1948) Soviet Property in Law and in Plan (with Special Reference to Municipal Land and Housing). University of Pennsylvania Law Review, vol. 96, no 3, pp. 324-353.

Besley T., Ghatak M.(2009) Property Rights and Economic Development. Handbook of Development Economics (eds. Rodrik D., Rosenzweig M.), vol. 5, Oxford: Elsevier, pp. 4525-4595.

Crawshaw J., Jackson J. (2010) Small Acts of Resistance: How Courage, Tenacity, and Ingenuity Can Change the World, New York: Union Square.

Dunn E.C., Verdery K. (2011) Dead Ends in the Critique of (post)Socialist Anthropology: Reply to Thelen. Critique of Anthropology, vol. 31, no 3, pp. 251-255.

Elyachar J. (2005) Markets of Dispossession: NGOs, Economic Development, and the State in Cairo, Durham: Duke University Press.

Ermishina A., Klimenko L. (2010) V poiskakh efektivnogo sobstvenika v mnogokvartirnom dome [In Search of an Efficient Owner in a Multi-family Residenial]. Economic Sociology, vol. 11, no 4, pp. 105-136.

Fehérváry K. (2013) Politics in Color and Concrete: Socialist Materialities and the Middle Class in Hungary, Indiana University Press.

Foucault M. (1978) The History of Sexuality. Vol. 1: An Introduction, New York: Random House. Gerasimova K. (1999) The Soviet Communal Apartment. Beyond the Limits: The Concept of Space in Russian History and Culture (ed. Smith J.), Helsinki: Studia Historica, pp. 107-130. 
Gerasimova K. (2000) Zhil'o v sovetskom gorode: istoriko-sotsiologicheskyj analys (Leningrad, 1918-1991) [Housing in a Soviet City: Socio-historical Analysis (The Case of Leningrad, 1918-1991)]. Available at: http://ecsocman.hse.ru/rubezh/msg/16298294.html, accessed 15.05.2019.

Gerasimova K. (2002) Public Privacy in the Soviet Communal Apartment. Socialist Spaces. Sites of Everyday Life in the Eastern Bloc (eds. Crowley D., Reid S.E.), New York: Berg Publishers, pp. 207-230.

Gluckman M. (1965) Politics, Law and Ritual in Tribal Society, Oxford: Basil Blackwell.

Gupta D. (2001) Everyday Resistance or Routine Repression? Exaggeration as Stratagem in Agrarian Conflict. Journal of Peasant Studies, vol. 29, no 1, pp. 89-108.

Hann C.M. (ed.) (1998) Property Relations: Re-newing the Anthropological Tradition, Cambridge, UK: Cambridge Universe Press.

Hann C.M., the Property Relations Group (2003) The Post-socialist Agrarian Question: Property Relations and the Rural Condition, Münster: LIT Verlag.

Hobson J., Seabrooke L. (2009) Everyday Politics of the World Economy, New York: Cambridge University Press.

Humphrey C. (1983) Karl Marx Collective: Politics, Society and Religion on a Siberian Collective Farm, Cambridge: Cambridge University Press.

Humphrey C. (2005) Ideology in Infrastructure: Architecture and Soviet Imagination. The Journal of the Royal Anthropological Institute, vol. 11, no 1, pp. 39-58.

Humphrey C. (2007) New Subject and Situated Interdependance: after Privatization in UlanUde. Urban Life in post-Soviet Asia (eds. Alexander C., Buchli V., Humphrey C.), London, pp. 175-207.

Humphrey C. (2013) Fear as a Property and an Entitlement. Social Anthropology, vol. 21, no 3, pp. 285-304.

Kideckel D.A. (1976) The Social Organization of Production on a Romanian Cooperative Farm. Dialectical Anthropology, vol. 1, no 3, pp. 267-276.

Kornai J. (1992) The Socialist System: The Political Economy of Communism, Oxford: Oxford University Press.

Latour B. (2005) Reassembling the Social: An Introduction to Actor-Network-Theory, Oxford: Oxford University Press.

Macfarlane A. (1998) The Mystery of Property: Inheritance and Industrialization in England and Japan. Property Relations (ed. Hann C.M.), University of Kent at Canterbury, pp. 104-123.

Marx K., Engels F. (1965/1932) The German Ideology, London: Lawrence \& Wishart.

McFaul M. (1995) State Power, Institutional Change, and the Politics of Privatization in Russia. World Politics, vol. 47, no 2, pp. 210-243.

Messana P. (2011) Soviet Communal Living. An Oral History of the Kommunalka, Palgrave Macmillan.

O’Brien K.J. (1996) Rightful Resistance. World Politics Journal, vol. 49, no 1, pp. 31-55.

O’Neill T., Gary H. (1994) All Politics Is Local, New York: Times Books.

Oleynik A. (ed.) (2005) The Institutional Economics of Russia's Transformation, Routledge.

Pipes R. (1999) Property and Freedom, London: Harvill.

Roland G., Aoki M., Milgrom P., Greif A. (2004) Transition and Economics: Politics, Markets, and Firms, MIT Press; New Ed edition.

Scott J.C. (1985) Weapons of the Weak: Everyday Forms of Peasant Resistance, New Haven: Yale University Press.

Smith M.B. (2010) Property of Communists: The Urban Housing Program from Stalin to Khrushchev, DeKalb: Northern Illinois University Press.

Verdery K. (1999) Fuzzy Property: Rights, Power and Identity in Transylvania's Decollectivization. Uncertain Transition: Ethnographies of Change in the Post-socialist World (eds. Burawoy M., Verdery K.), Lanham, Md.: Rowman \& Littlefield, pp. 53-82.

Verdery K. (2003) The Vanishing Hectare: Property and Value in Post-socialist Transylvania, Ithaca, NY: Cornell University Press.

Verdery K., Humphrey C. (eds.) (2004) Property in Question: Value Transformation in the Global Economy, Oxford: Berg.

Walder G., Isaacson A., Lu Q. (2015) After State Socialism: The Political Origins of Transitional Recessions. American Sociological Review, vol. 80, no 2, pp. 444-468. 